\title{
Further Investigations on the Financial Characteristics of Credit Default Swap(CDS) spreads for Korean Firms
}

\author{
Hanjoon $\mathrm{Kim}^{1^{*}}$ \\ ${ }^{1}$ Dept. of Business Administration, Hoseo University \\ 국내기업들의 신용부도스왑(CDS) 스프레드의 재무적 특성에 관한 \\ 심층분석 연구 \\ 김한준 ${ }^{*}$ \\ ${ }^{1}$ 호서대학교 사회과학대학 경영학과
}

\begin{abstract}
This study examined the background of the recent global financial crisis and the concept of one of the financial derivatives such as the credit default swap(CDS) or synthetic $\mathrm{CDO}$ (collateral debt obligations), given the rapid growing and changing the over-the-counter derivative markets in their volume and structures. In comparison with the previous literature such as the study of Park \& Kim (2011), this research empirically performed more thorough and comprehensive investigations to find any financial characteristics or attributes to determine the CDS spreads. Regarding the results obtained from the multiple regression models, the explanatory variables such as STYIELD3, SLOPE, INASSETS, and VOLATILITY, showed their statistically significant effects on all the tested dependent variables(DVs). Another procedure such as the principle component analysis(PCA), was also performed to account for additional IDVs as possible determinants of the dependent variables. Subsequent to this analysis, larger coefficients of each corresponding eigenvector such as BETA, PFT2, GROWTH, STD, and BLEVERAGE were found to be possible financial determinants. For robustness, all the IDVs were employed to be tested in the 'full' regression model with stepwise procedure. As a result, STYIELD3, SLOPE, and VOLATILITY, and BETA showed their statistically significant relationship with all the dependent variables of the CDS spreads.
\end{abstract}

요 약 본 연구에서는 미국발 금융위기의 근본 원인과 국내,외 금융시장에서 관심의 대상이 되고 있는 장외파생상 품의 일종인 신용부도스왑(Credit Default Swap, CDS) 혹은 합성부채담보부채권에 대한 내용을 사전적으로 분석하였 다. 2007년부터 문제화가 되기 시작한 미국발 금융위기의 근본 배경으로서, 2000년부터 2008년 초까지 약 5 배나 급 속히 상승한 국제유가 요인 등이 동 위기의 기조원인으로서 분석되었다. 기존의 국내기업 관련 $\mathrm{CDS}$ 스프레드 분석 연구결과 등과 비교하여(예: Park \& Kim, 2011), 본 연구에서는 일반성(commonality)과 견고성(robustness)의 제고를 위하여, 해당 실증적 방법론과 변수들(즉, 산업별 더미변수들 포함한 총 18 가지의 설명변수들과 종속변수들(3가지))의 활용에서도, 더욱 포괄적이고 심층적인 분석을 수행하고자 하였다. 결과와 관련하여, 종속변수인 CDS 스프레드의 재 무적 특성 혹은 결정요인으로서, 4 가지 설명변수들 (무위험수익률, 이자율의 기간구조, 자산의 크기, 변동성)이 다중회 귀모형을 통하여 각각의 통계적인 유의성 $5 \%$ 신뢰수준)을 나타낸 반면, 추가적인 설명변수의 발견을 위하여 주성분분 석을 사용한 결과, 5 가지 변수들(체계적 위험(베타), 수익성, 매출액 성장성, 변동성, 장부상 부채비욜)이 CDS 스프레 드에 대한 유의성을 보였다. 상기 결과들의 robustness 제고를 위하여, 사용된 총 18 가지의 설명변수를 종합적으로 활 용한 '단계적 회귀식(stepwise regression)'의 결과에서는 $\mathrm{CDS}$ 스프레드의 대용치인 모든 종속변수에서, 다음의 4 가지 설명변수들이 결정요인으로서 발견되었다: 무위험수익률, 이자율의 기간구조, 변동성, 체계적 위험(베타). 또한, 산업별 유의성 관련, 수출주도형 산업으로 분류되는 자동차산업과 철강산업은 종속변수와 음(-)의 상관관계를 나타낸 반면, 내수업종인 통신서비스업종은 양(+)의 유의성을 보였다.

Key Words : Credit Default Swap(CDS), Financial Characteristics, Korean Firms, Multiple Regression, Principle Component Analysis(PCA)

\footnotetext{
This research was supported by the Academic Research fund of Hoseo University in 2012. [\# 2012-0289]

${ }^{*}$ Corresponding Author : Kim, Hanjoon

Tel: +82-10-4797-5777 email: khj723@hoseo.edu
}

Received August 14, 2012 Revised September 3, 2012 Accepted September 6, 2012 


\section{Introduction}

This study academically examines an empirical issue that has received little attention in the finance literature: the financial characteristics or attributes of the credit default swap(CDS) spreads (or premia) for Korean firms belonging to emerging capital markets. Coupled with describing the brief history and the structure of this new financial innovative product, the CDS, it may be interesting to thoroughly investigate the financial determinants, due to very few research tested empirically on the theoretical implication of each possible determinant for Korean firms belonging to emerging capital markets. In comparison with the previous literature reviewed in the following section, this research would empirically perform more thorough and comprehensive investigations on finding any financial characteristics or attributes to determine the CDS spreads in level or proportion. By taking into account of the results utilizing several major methodologies, professionals or investors may effectively analyze and/or control the spreads at their country- and firm-levels. Furthermore, when selecting a time (or studied) period of this particular study (i.e. between the year of 2009 and 2010), more consideration was given to the motivation to investigate any new or changing financial characteristics of the CDS spreads in the 'post-global financial crisis' after the recent global financial crisis, with minimizing any possible spillover effects form the event.

For a practical purpose, given that the recent U.S. financial crisis primarily resulted from the mortgage-related issues, the so-called as 'sub-prime mortgage problem', has been, in large part, originated due to the following macroeconomic missteps: the global BOP imbalance and the misguided monetary policy.[1] Regarding the monetary policy issue, it was generally known that, since the 2000-01 tech-stock collapse and the subsequent 9-11 disaster, the prolonged interest policy of the Fed was to keep domestic interest rates lower to recover the sluggish global and the domestic economies, as described in their study. Considering the global market condition with the low interest rate policy, investors may well look for more competitive financial products which were mainly created by major investment banks or consulting firms to achieve their high investment yields. As byproduct, credit default
swap(CDS) referred to as synthetic collateralized debt obligation(Synthetic CDO), was actively spread over and favored by professionals participated in the capital markets to exploit any arbitrage profit.[2]

The major objectives or motivation to perform this particular study can be summarized as follows: First, there has been increasing interests or needs from potential (domestic) investors who may have less knowledge on the financial derivatives such as CDS, given the rapid growing and changing over-the-counter(OTC) derivatives markets in their volume and structures. Secondly, there were few systematic comparisons on the results of the possible determinants of CDS spreads especially, for the firms belonging to emerging capital markets, even if most previous researches were focused on or performed for the firms located in advanced capital market regions, as described previously. Therefore, policy makers implementing the domestic financial policies in Korea or emerging capital markets, may consider the implications of the significant results obtained from this research to prevent or minimize any possibilities of unanticipated financial turmoil. Moreover, such a comparison on the results between advanced and emerging capital markets, may be mutually beneficial or helpful for the firms belonging to both markets, given the on-going free trade agreements(FTAs) including financial aspects among nations.

This study is composed as follows: The second section illustrates the historical background and the concepts of the OTC financial derivatives such as CDS and CDO, followed by the introduction section. To derive any possible financial attributes of the CDS spreads for the Korean sample firms classified into the emerging capital market, major methodologies such as the full regression model and the principle component analysis(PCA), were described in the third section with the data collection criteria. The results are then analyzed and interpreted in the next section, followed by the final section presenting a summary and conclusions. 


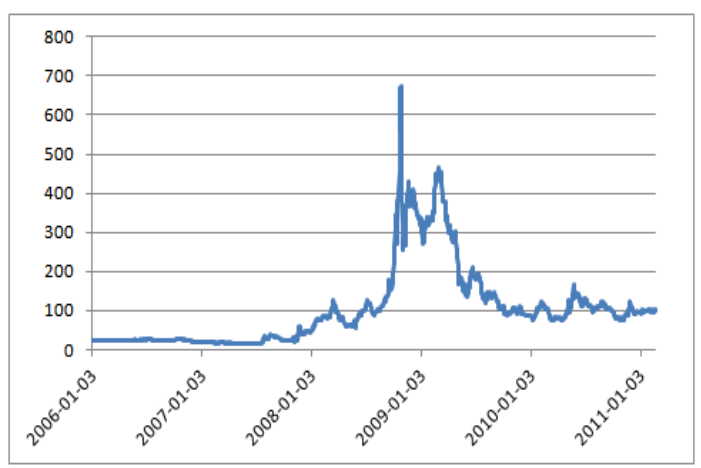

[Fig. 1] Korea's 5-year CDS premium (Unit: b.p.) (Source: Bloomberg Database)

\section{Review on the Credit Default Swap(CDS) and Previous Literature}

\subsection{The Background and the Structure of CDS (synthetic CDO)}

This recent financial crises seemed to surge from the bailout by the German government for their domestic banks such as IKB and SachsenLB suffering from the investment losses of sub prime mortgage securities in the middle of 2007. This situation eventually spread to the U.S. economy and was even worsened by the sluggish housing markets in U.S. related to the sub prime mortgage exposure. As one of the underlying external factors to have an adverse influence on the global and the U.S. domestic housing markets, none may deny the drastically increasing oil prices between the period of the beginning of the 2000s and thereafter until July 2008. The price of crude oil in terms of WTI, increased as much as five-fold between the September (9-11), 2001 (about \$20) and March, 2008 (\$97).

Coupled with the underlying macroeconomics factors such as the global BOP imbalance and the misguided monetary policy resulting in the excessive liquidity as discussed earlier, the U.S. sub prime mortgage crisis has also been resulted from the enactment of a law such as the Community Reinvestment Act to make more flexible loans to poorer neighborhood. However, the primary cause of the so-called as 'U.S. sub prime mortgage crisis' affecting the recent international financial crisis, may result from the abuse of various innovative financial techniques including newly created financial products.[3] In other words, many sophisticated and innovative financial products were misused and even utilized for the ill-purposes by some professional participants to fulfill their greed or excessive desire. Besides the traditional mortgage loans such as MBS(Mortgage Backed Securities) and CMOs(Collateralized Mortgage Obligations), 'securitization', one of the global trends in financial markets, helped to create CDOs (Collateralized Debt Obligations): One of the classifications was known as 'synthetic CDO' or CDS (Credit Default Swap), whose structure was similar to that of insurance.

First, CDOs were first introduced in the U.S. capital markets by Drexel Burnham Lambert Inc. in 1987. The underlying collaterals or assets of this, new innovative products include not only newly launched traditional mortgage loans in the markets, but also already existing MBS and CMOs. Regarding the structure of CDOs, they were created in tranches of the underlying debt that have different degree of their riskiness and maturities and this allows CDO creator to sell various investors on a separate and individual tranche basis, commensurated with their own risk preference.(Park \& Kim[4]) The main advantages of the CDOs over conventional structured products (such as MBS and CMOs), may result from the fact that they do not need a supply of new mortgage loans, since their collaterals need not be confined to "new" mortgage loans, thus the banking industry was able to form a new securities like CDOs utilizing as collaterals existing traditional financial products as well as financial derivatives such as CDS.[5] To examplify the structure of CDS, party A, called as a protection buyer, purchases credit protection on a reference securities (or obligations) such as a bond or loan issued by a particular issuer, from a protection seller. Party A purchasing protection, pays the seller, (called as a protection seller), a fixed payment on a regular interval like an insurance premium until a credit event (i.e. bankruptcy or unexpected credit problems), or until the maturity of the swap contract.[6] In terms of the option structure, a protection seller of CDS may take a put option writer on the underlying assets of CDOs. Synthetic CDO is also a portfolio of financial derivatives composed of CDS. CDS (or synthetic CDOs) has peaked in the year of 2007, amounting to $48,470.5$ in billions of U.S. dollars.[7] 


\subsection{Previous Literature}

Blanco et al.[8] performed their study to model the dynamics of the two measures of credit risk, such as CDS prices and credit spreads. With the sample data of 33 reference entities in the U.S. and Europe, empirical analyses were implemented to model the dynamics of the credit risks by using several categories of the independent variables, suggested by finance theory. They found that macro-variables including interest rates, term structure, equity market returns, and equity market implied volatilities, have a larger immediate impact on credit spreads than on CDS prices, while firm-specific variables such as equity returns and implied volatilities have a greater effect on CDS prices than on spreads, both in terms of absolute magnitude and level of significance. They described that lagged adjustments of the credit spreads to the CDS prices, may be necessary for price discovery, since both CDS prices and credit spreads are equally sensitive to these variables in the long run. Abid \& Naifar[9] also tested the possible determinants of credit default swap price and the drivers of default risk during the period of May, 2000 to May 2001. Total 73 credits consisting of the sample data were obtained from eleven European countries. Among the five independent variables, the slope of the yield curve was measured as the difference between the long-and short-term interest rate. For example, the spread between the European government bond yield (as a long-term rate) and the French interest rate as a short-term one was calculated as a proxy for the slope. Credit ratings were found to be the most statistically significant attribute to explain the prices of CDS. While the slope of the yield curve and free risk interest rate as determinants showed their significant influence on the CDS prices, systematic risk and standard deviation on equity return could not show their effects on the price.

The study done by Avramov et al.[10] was to test the potential determinants of credit spread changes, not its level. Even if this study may not be directly related to find any characteristics or effects on CDS premium or spread, the results obtained may imply the possible determinants of the premium to be considered. Based upon a larger number of the sample data(2,375 corporate bonds including high-yield bonds), the results obtained, revealed that idiosyncratic volatility and the price-to-book ratio have statistically significant influence on the time-series variation in corporate credit-spread changes. Overall, there was strong evidence that company-level variables combined with common factors, explained more than 53 percent of the variation in credit-spread changes (measured in adjusted $\mathrm{R}^{2}$ ), which is statistically significant in F-statistic.

The research investigated by Ericsson et al.[11] was to find any relationship between default swap spreads and independent variables including firm leverage, volatility, and riskless yields. The data for the spreads covering the period of 1999 - 2002 on senior debt, were utilized as the sample. On the general results of the levels regression and the difference regression obtained in this study, the estimated sign for the statistically significant coefficient on leverage was positive, as expected a priori in finance theory. Second, the estimated sign for the coefficient on volatility was positive with its coefficient being statistically significant. Third, the coefficient on the 10-year yield as a proxy for riskless yield also confirmed to theoretical expectations because it showed a negative sign.

The study performed by Greatrex[12] utilized regression analyses to explore the ability of structural variables to explain the variation in CDS spread changes. They employed the five-year maturity contract price to calculate the changes of the spread, taking into account of its accessibility with most commonly traded maturity. Especially, two legs of CDS spread changes were used to control for autocorrelation in the study. By employing nine explanatory variables to be applied to the multivariate regressions, they found that leverage and volatility were key determinants of CDS spread changes, since these two variables explained about half of the variation for the dependent variable. The coefficient on a CDS rating-based index was consistently positive in its sign, and statistically significant in the estimated models. Kim \& Lee[13] suggested two methods for determining Korean won (KRW)-denominated CDS spread: One method used the market quotes of dollar-denominated CDS, whose reference entities were dollar-denominated bonds issued by domestic firms. The other one utilized the credit spreads of won (KRW)-denominated risky bonds. To test for the determinants of KRW -denominated CDS spread by utilizing the former method, they found 
that volatility of KOSPI200 options and KOSPI200 returns were statistically significant factors affecting the spread. However, the Korean treasury bond yields and the spreads between Korean long-term bond yields and short-term bond yields were the significant ones in the latter method, but not in the former. They explained that this conflicting aspect may in part, have resulted in or shown the difference between the two methods when determining KRW-denominated CDS spread.

Among the independent variables(IDVs) employed in the study of Park \& Kim[14], they found that the three-year Korean treasury yield as a proxy for the risk-free rate, showed its significant and positive significance on the changes of the CDS premia(CHANAGE) The ex-ante expectations or arguments relating to the relationship between the interest rate effect and a firm's CDS premium, may be a statistically significant, but a negative one from the previous empirical findings such as [15] and [16]. The coefficient for the size variable showed a negative and statistically significant influence, which indicates that larger size of a firm is related to lower dependent variable(DV), which was expected in the finance theory. Finally, market value/book value ratio(MV/BV), the proxy for growth opportunities for a company, showed its statistical significance at the $5 \%$ level with a negative coefficient $(=(-) 0.02471)$ in Result A. This finding is consistent with the testing result performed by Avramov et al.[17].

\section{Data Collection and Methodologies}

\subsection{Sampling Criteria}

This study collected recent financial data (the years of 2009 and 2010) on the CDS spreads and explanatory variables, which were illustrated below. When selecting a studied period of this particular study, consideration was given to the motivation to investigate any new or changing financial characteristics of the CDS spreads in the 'post-global financial crisis' following the recent global financial crisis with minimizing any possible spillover effects form the event. The followings are the sampling criteria employed for the Korean sample firms:
[Table 1] The Sampling Criteria

First, the sample firms should be included in the population of Bloomberg Database and

NewKISValue headquartered in the republic of Korea.

Second, all of the data for each corporation should be available for at least 2 years from the year of 2009 to 2010 .

Third, financial and regulated industries were not included in the sample.

Fourth, the method linear interpolation was

utilized to obtain daily based estimates to

employ in the model, as described in Blanco

(2005) and Greatrex(2009).

Based on the criteria, the final sample firms were composed as follows: Hyundai Motor, KT Telecom, Korea Electric Power, POSCO, SK Telecom, and Samsung Electronics.

\subsubsection{Definition of the Variables employed in the models}

To find the possible determinants of the CDS premium for the Korean firms, each test with its corresponding dependent variable(DV) such as CHANGE1, CHANGE2, and CHANGE3 was separately carried out in the context of a multiple regression with stepwise procedure, whose corresponding definition was explained later. In the previous literature, most empirical tests on the determinants of CDS spread were performed, based on either the 'level' or 'change' of CDS spread for the dependent variables employed. However, there are a controversial issue to consider when selecting DV on the 'level' or 'change' basis. The former may encounter the major econometric problems such as the possible violations of non-stationarily in the time-series analysis. "The focus of this study is on changes in CDS spreads as opposed to levels because stationarity tests find CDS spread levels to be non-stationary, while CDS spread changes are stationary. Thus, focusing on spread changes is important from a statistical point of view to avoid spurious regression inferences."[18] However, if the latter DV was selected to test for the financial attributes, the explanatory power of the multiple regressions measured by 'adjusted $\mathrm{R}^{2}$ ', may show its lower power to explain 
the model, as described in Ericsson et al.[19]. Taking into account this controversial issue, this paper utilized both DVs such as CHANGE1 for a 'change in proportion' of CDS spreads and CHANGE2 for a 'level', respectively, to find robust results on the financial determinants of the CDS spreads For a cross check purpose, another dependent variable(CHANGE3) with two-lagged time difference, was also employed to reduce any possibility of non-stationality and autocorrelation, which may otherwise incur any spurious inferences, as explained in Greatrex[20].

With respect to the independent variables(IDVs), three categories with total eighteen variables were employed to test for the possible determinants of the CDS premium for the Korean sample firms. The categories are classified as follows: Macroeconomic variables, Firm-specific variables, and Industry dummy variables.

Since these IDVs selected and entered into the model, were based upon their commonalities as the explanatory variables in most previous literature, the results obtained from this study may be utilized to interpret their similar or different patterns between advanced and emerging capital markets, as discussed. The IDVs as possible determinants, were size(INASSETS), profitability(PFT1, PFT2), volatility(VOLATILITY, STD), market value based leverage(MLEVEAGE), book value based leverage (BLEVERAGE) market value to book value of equity(MVBV), market capitalization(MVE), risk-free interest rate(STYIELD3, TYIELD3), term structure of interest rate(SLOPE), the growth rate in sales(GROWTH) and the beta coefficient(BETA) for each sample firm, as illustrated in Table 2. Besides th IDVs, four industry dummy variables with a base one for the semiconductor industry, were used to find any significant effect on the CDS spreads, in that industry effect may be one of the prolonged controversial issues in the finance literature. ([21], [22]). Therefore, total eighteen explanatory variables including the industry dummies, were employed and separately tested in each corresponding model, such as the multiple regression model and the principle component analysis(PCA) to find any possible determinants of the CDS spreads for the Korean sample firms as presented below.

\subsection{Multiple Regression Analyses}

(with and without stepwise procedure)

The following is the multiple regression model to be estimated by the OLS procedure:

CHANGE(1, 2 or 3$)$ it $=$ b0 + b1INASSETSit

+ b2PFT1it + b3VOLATILITYit

+ b4MLEVERAGEit + b5SLOPEit

+ b6STYIELD3it + b7MVBVit + b8IND1it

+ b9IND2it + b10IND3it + b11IND4it + eit

Where,

$\mathrm{i}=1,2,3 \cdots \cdots, \mathrm{n}$ (companies),$\quad \mathrm{t}=$ From $1 / 4 / 2009$ to

$12 / 30 / 2010$

<Dependent Variables(DVs) $>$

CHANGE1 $=$ Daily change of CDS premium in proportion

CHANGE2 $=$ The level of CDS premium

CHANGE3 $=$ Two lagged time difference as [CHANGE1(t+2) - CHANGE1(t)]

\section{<Independent Variables(IDVs)>}

INASSETS, PFT1, VOLATILITY, MLEVERAGE, MVBV, SLOPE, STYIELD3 with the following industry dummy variables (Refer to Table 2)

Ind $1=1$ if a sample firm belongs to the automobile industry. 0 , otherwise.

Ind2 $=1$ if a sample firm belongs to the electricity and gas industry. 0 , otherwise.

Ind $3=1$ if a sample firm belongs to the telecommunication industry. 0 , otherwise.

Ind $4=1$ if a sample firm belongs to the steel industry 0 , otherwise.

$\mathrm{e}_{\mathrm{it}}$ is the error term assumed to be normally distributed, homoscedastic, and independent.

\subsection{Principal Component Analysis (PCA)}

Coupled with the regression results, the principal component analysis(PCA) was to be applied to find another 'new' IDVs, if the constant term of the previous regression procedure shows its statistically significant effect, as similarly presented in [23] and [24]. The basic rationale of the PCA is to create new ' $n$ ' variables, $C 1$, 
$\mathrm{C} 2, \ldots \ldots ., \mathrm{Cn}-1, \mathrm{Cn}$. These new variables called 'Principal Components' are the linear functions of IDVs, which may be considered as possible financial characteristics of the CDS speads in this particular research.[25]:

$$
\begin{aligned}
\mathrm{C} 1 & =\mathrm{a} 11 \mathrm{X} 1+\mathrm{a} 12 \mathrm{X} 2+\ldots \ldots+\mathrm{a} 1 \mathrm{nXn} \\
\mathrm{C} 2 & =\mathrm{a} 21 \mathrm{X} 1+\mathrm{a} 22 \mathrm{X} 2+\ldots \ldots+\mathrm{a} 2 \mathrm{nXn} \\
& \ldots \ldots \ldots \ldots \ldots \ldots \ldots \ldots \ldots \ldots \ldots \ldots \ldots \ldots \ldots \ldots \ldots \ldots \ldots \ldots \ldots \ldots \ldots \\
\mathrm{Cn} & =\mathrm{an} 1 \mathrm{X} 1+\mathrm{a} 2 \mathrm{X} 2+\ldots \ldots+\mathrm{annXn}
\end{aligned}
$$

The set of coefficients of the linear combination for the ith principal component is the ith eigenvector which is chosen to satisfy the following conditions:

1. $\operatorname{Var}(\mathrm{Ci})$, eigenvalue, is as large as possible

2. The $\mathrm{N}$ values (of observations) of $\mathrm{Ci}$ and $\mathrm{Cj}$ are uncorrelated.

3. $\mathrm{a}^{2} 11+\mathrm{a}^{2} 12+\ldots \ldots+\mathrm{a}^{2} 1 \mathrm{n}=\ldots \ldots=\mathrm{a}^{2} \mathrm{n} 1+\mathrm{a}^{2} \mathrm{n} 2$ $+\ldots . .+a^{2} n n=1$

As for the new explanatory variables of the PCA, seven IDVs such as BETA as a proxy for systematic risk, PFT2 as for profitability, GROWTH for growth rate in sales, TYIELD3 for risk-free interest rate, STD for business risk, MVE for market capitalization, and BLEVERAGE for book-value based leverage ratio, were employed with four industry dummies, whose definitions were presented in the following table.

\begin{tabular}{|c|c|c|}
\hline \begin{tabular}{|c|} 
Book value \\
based leverage
\end{tabular} & \begin{tabular}{|c|} 
BLEVER \\
AGE \\
\end{tabular} & Total liabilities / Total assets \\
\hline \begin{tabular}{|c|} 
Market value \\
to book value \\
of equity
\end{tabular} & MVBV & $\begin{array}{l}\text { Market value of equity / book } \\
\text { value of equity }\end{array}$ \\
\hline \multirow[t]{2}{*}{$\begin{array}{l}\text { Risk-free } \\
\text { interest rate }\end{array}$} & $\begin{array}{c}\text { STYIELD } \\
3 \\
\end{array}$ & \begin{tabular}{|lll}
$\left(\begin{array}{l}\text { Three-year } \\
\text { yield })^{2}\end{array}\right.$ & Korean & treasury \\
\end{tabular} \\
\hline & TYIELD3 & Three-year Korean treasury yield \\
\hline $\begin{array}{l}\text { Term structure } \\
\text { of interest rate }\end{array}$ & SLOPE & $\begin{array}{l}\text { Five-year Korean treasury minus } \\
\text { three-year Korean treasury yield }\end{array}$ \\
\hline \begin{tabular}{|c|} 
Market \\
Capitalization \\
\end{tabular} & MVE & Common equity at market value \\
\hline A firm's beta & BETA & $\begin{array}{l}\text { a firm's beta on a daily return } \\
\text { during one year period. }\end{array}$ \\
\hline Growth rate & GROWTH & $\begin{array}{l}\text { annual geometric growth rate in } \\
\text { sale }\end{array}$ \\
\hline Industry & $\begin{array}{l}\text { IND1, } \\
\text { IND2, } \\
\text { IND3, } \\
\text { IND4 }\end{array}$ & $\begin{array}{l}\text { Dummy variable representing the } \\
\text { corresponding industry to which } \\
\text { each Korean sample firm belongs. } \\
\text { Base industry-[The control group] } \\
: \\
\text { the semiconductor industry } \\
\text { IND1: the automobile industry } \\
\text { IND2: the electricity and gas } \\
\text { industry } \\
\text { IND3: the telecommunication } \\
\text { industry } \\
\text { IND4: the steel industry }\end{array}$ \\
\hline
\end{tabular}

[Table 2] Definition of the Independent Variables(IDVs)

\begin{tabular}{|c|c|l|}
\hline Definition & $\begin{array}{c}\text { Proxy } \\
\text { Variable }\end{array}$ & \multicolumn{1}{|c|}{ Measurement } \\
\hline Size & $\begin{array}{c}\text { INASSET } \\
\text { S }\end{array}$ & $\begin{array}{l}\text { Natural Log of Book value of } \\
\text { assets at the fiscal year-end }\end{array}$ \\
\hline Profitability & PFT1 & $\begin{array}{l}\text { Earnings before interest and } \\
\text { taxes(EBIT)/Book value of } \\
\text { assets at the fiscal year-end }\end{array}$ \\
\cline { 2 - 4 } & PFT2 & Net income / Book value of assets \\
\hline Volatility & STD & $\begin{array}{l}\text { Standard deviation of the changes } \\
\text { in EBIT during the sample period }\end{array}$ \\
\cline { 2 - 4 } & VOLATIL & $\begin{array}{l}\text { (Annual equity return) x Total } \\
\text { daily number of equity trading } \\
\text { during a particular year) }\end{array}$ \\
\hline $\begin{array}{c}\text { Market value } \\
\text { based leverage }\end{array}$ & MLEVER & $\begin{array}{l}\text { Total liabilities at book value / } \\
\text { AGE } \\
\text { (Total liabilities at book value }+ \\
\text { Total preferred stock at book } \\
\text { value + common equity at market } \\
\text { value) }\end{array}$ \\
\hline
\end{tabular}

\section{Analyses and Interpretations}

Based upon the results from the models such as the multiple regression and the principal component analysis, each IDV employed in the models were analyzed for its implications. Moreover, for a cross-checking purpose, all the explanatory variables across the models, were selected and included in the 'full' regression model, the so called as the 'kitchen sink regression' model, with stepwise procedure, to find possible characteristics of the Korean CDS spreads for the sample firms. As a general rule to interpret the results in this empirical study, the statistically significant IDVs at the 5\% level of significance (or in their p-values), were first analyzed to find the possible determinants of the CDS spreads, while any notable implications derived from the parameter estimates of IDVs, even if insignificant, were also presented for future reference, if necessary.

\subsection{Analyses}

\subsubsection{Results on the multiple regressions}


[Table 3] Results from the regression for each dependent variable(DV)

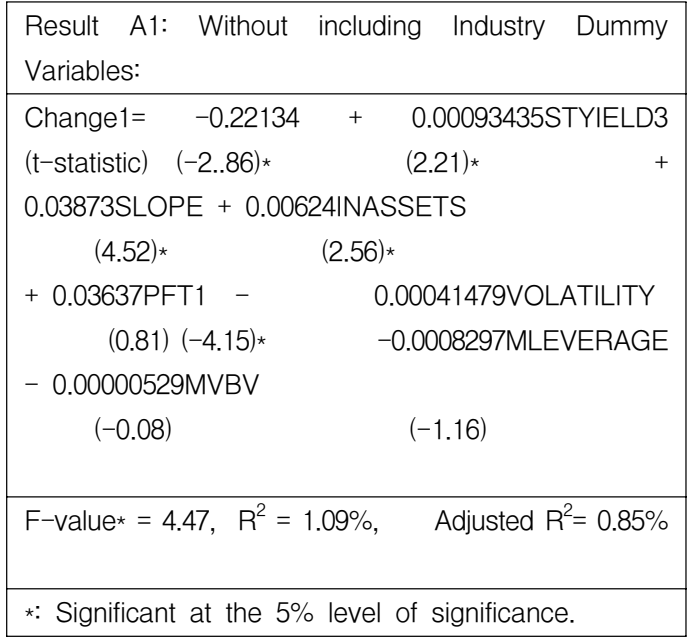

Result A2: Without including Industry Dummy

Variables:

Change2 = $2551.742-11.35019$ STYIELD3

(t-statistic) (22.32)* $\quad(-18.19)$ *

+284.496 SLOPE -87.08835 INASSETS

(22.45)* $\quad(-24.23) \star$

-162.469 PFT1 + 6.94674VOLATILITY

$(-2.44) * \quad(47.00) *$

+ 179.285MLEVERAGE +0.10696MVBV

(11.74)*

(15.82)

F-value $* 653.12, \quad R^{2}=61.8 \%, \quad$ Adjusted $R^{2}=$ $61.7 \%$

$\star$ : Significant at the $5 \%$ level of significance.

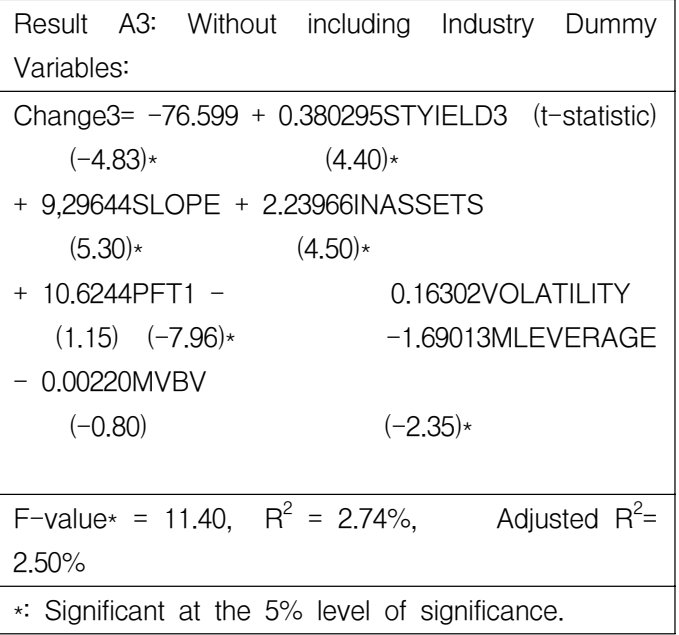

Regarding the results obtained from the multiple regression analyses[Table 3], the explanatory variables such as STYIELD3, SLOPE, INASSETS, and VOLATILITY, showed their statistically significant effects on all the tested dependent variables including CHANGE1, CHANGE2, and CHANGE3. As indicated, the DVs of CHANGE1, CHANGE2 and CHANGE3 represent a daily change of CDS spreads in proportion, a level of CDS spreads, two lagged time difference as [CHAGNE1(t+2) CHAGNE1(t)], respectively.

Stepwise regression procedure was also employed in this stage to utilize its ability to derive more parsimonious model that may be relatively free of multicollinearity, in the sense that every variable in the final model would be guaranteed to add significant incremental predictive value.[26]. Moreover, by employing this procedure, one may expect to mitigate feasible econometric problems such as heteroscedasticity and autocorrelation in the error term for the panel data (both cross-sectional and time series data), as presented in Palenzuela and Bobillo[27] Through the stepwise analyses on the same DVs for a cross-check purpose, it was found that SLOPE and VOLATILITY among the previous four significant IDVs, consistently showed their statistically signifiant influence as possible financial attributes to determine the CDS spreads of the Korean firms. Furthermore, on the results from the regression analyses 'with' including the industry dummy variables, the IDVs such as STYIELD3, SLOPE, and VOLATILITY were found to be statistically significant across all DVs, while SLOPE and VOLATILITY were only significant variables after applying the stepwise regression procedure to each model. However, the industry effect utilizing each corresponding dummy variable did not show their consistent results on the DVs of the CDS spreads.

As one of the controversial issues on the DV measured by either the 'change'(CHANGE1) or the 'level' (CHANGE2) of the CDS spreads as described earlier, it was found that the adjusted $\mathrm{R} 2(=0.85 \%)$ relating to CHANGE1 was much lower than that $(=61.7 \%)$ of the Change2, as shown in Table 3(Result A1 \& Result A2), which was consistent with the findings in Ericsson et al.[28] and Park \& Kim[29]. Similar result was also available to the regression model with industry dummies, which provided that the adjusted $\mathrm{R}^{2}(=0.0 .80 \%)$ of 
CHANGE1 was lower that $67.2 \%$ of adjusted R2 relating to CHANGE2.

\subsubsection{Results on the Principle component analyses(PCA)}

[Table 4] Results from the principle component analysis (PCA) with new independent variables(IDVs)

Result B1: PCA Without Industry Dummy Variables

1. Eigenvalues of the Correlation Matrix:

\begin{tabular}{|l|l|l|}
\hline $\begin{array}{l}\text { Principle } \\
\text { Component } \#\end{array}$ & Proportion & Cumulative \\
\hline PC 1 & 0.4253 & 0.4253 \\
\hline PC 2 & 0.2646 & 0.6899 \\
\hline PC 3 & 0.1449 & 0.8348 \\
\hline PC 4 & 0.1159 & 0.9507 \\
\hline PC 5 & 0.0407 & 0.9914 \\
\hline PC 6 & 0.0073 & 0.9987 \\
\hline PC 7 & 0.0013 & 1.0000 \\
\hline
\end{tabular}

\section{Eigenvectors:}

\begin{tabular}{|l|l|l|}
\hline IDV & PC 1 & PC 2 \\
\hline Beta & 0.430197 & 0.465238 \\
\hline Pft2 & 0.366174 & -0.428730 \\
\hline Growth & 0.361860 & 0.465012 \\
\hline Tyield3 & -0.022290 & 0.048711 \\
\hline STD & 0.500679 & 0.155318 \\
\hline MVE & 0.461752 & -0.294801 \\
\hline Bleverage & -0.292425 & 0.519715 \\
\hline
\end{tabular}

\begin{tabular}{|c|c|c|}
\hline \multicolumn{3}{|c|}{ Result B2: PCA With Industry Dummy Variables } \\
\hline \multicolumn{3}{|c|}{ 1. Eigenvalues of the Correlation Matrix: } \\
\hline $\begin{array}{l}\text { Principle } \\
\text { Component \# }\end{array}$ & Proportion & Cumulative \\
\hline PC 1 & 0.3517 & 0.3517 \\
\hline PC 2 & 0.2507 & 0.6024 \\
\hline PC 3 & 0.1539 & 0.7564 \\
\hline PC 4 & 0.1331 & 0.8895 \\
\hline PC 5 & 0.0912 & 0.9807 \\
\hline PC 6 & 0.0107 & 0.9914 \\
\hline PC $7,8,9,10,11$ & 0.0086 & 1.0000 \\
\hline
\end{tabular}

2. Eigenvectors:

\begin{tabular}{|l|l|l|}
\hline IDV & PC 1 & PC 2 \\
\hline Beta & 0.474174 & 0.165547 \\
\hline
\end{tabular}

\begin{tabular}{|l|l|l|}
\hline Pft2 & 0.194389 & -0.490673 \\
\hline Growth & 0.444034 & 0.152220 \\
\hline Tyield3 & -0.009014 & 0.029095 \\
\hline STD & 0.416311 & -0.010200 \\
\hline MVE & 0.260766 & -0.333013 \\
\hline Bleverage & -0.117841 & 0.537286 \\
\hline IND1 & 0.150539 & 0.413412 \\
\hline IND2 & -0.009814 & 0.287832 \\
\hline IND3 & -0.472145 & -0.163933 \\
\hline IND4 & 0.198103 & -0.165853 \\
\hline
\end{tabular}

As shown in Table 4, the first principle component(PC) accounted for $42.53 \%$ [Result B1] and 35.17\%[Result B2], while the proportions of the second principle component were $26.46 \%$ and $25.07 \%$, respectively. Thereby, these results in the cumulative proportions of the analyses (i.e. without and with industry dummies) were calculated as $68.99 \%$ and $60.24 \%$, comprising only the first and the second PCs, respectively. Since the methodology of the principal component analysis is primarily utilized for an explanatory purpose[30], a new explanatory variable as a possible determinant of the CDS spreads was selected, based on larger coefficient of each corresponding eigenvector i.e. the set of coefficients of each PC), whose value was larger than 0.40 in absolute term in this research. Among all of the employed IDVs (i.e. eleven IDVs including industry dummies), five IDVs such as BETA, PFT2, GROWTH, STD, and BLEVERAGE were estimated as additional determinants to explain the CDS spreads, as presented in Table 4 .

\subsubsection{Results on the full regression ('kitchen sink' regression) for robustness}

[Table 5] Results from the 'full' regression for each dependent variable(DV) with a stepwise procedure

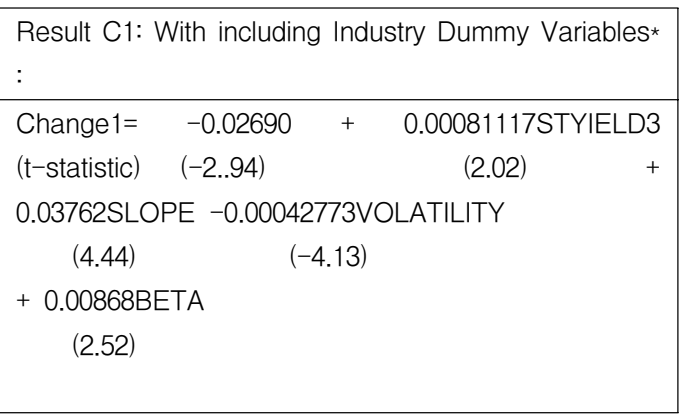




\begin{tabular}{l}
\hline -value $=7.64, \quad R^{2}=1.07 \%, \quad$ Adjusted $R^{2}=0.93 \%$ \\
\hline$*$ The significant levels for entry and staying in the \\
stepwise procedure were controlled at the 0.05 level, \\
respectively.
\end{tabular}

Result C2: With including Industry Dummy Variables*:

Change2 $=16082-14.60075$ STYIELD3

(t-statistic) (12.76) (-25.47)

+ 162.98362SLOPE -798.93167INASSETS

(15.62)

$(-19.36)$

+ 6401.29919PFT1 + 2.25536VOLATILITY

(15.07)

(8.77)

+ 295.26432MLEVERAGE -1.57483MVBV

(4.01)

$(-23.96)$

-224.40002BETA -15416PFT2

$(-14.34)$

$(-19.79)$

+72480GROWTH +2.12125E-10STD

(31.49)

+2.15157E-14MVE + 978.5867BLEVERAGE

$(25,61)$

-4894.765 IND1 + 4921.926IND3

$(-29.02)$

(28.82)

-5671.877 IND4

$(-30.08)$

F-value* $=602.78, \quad R^{2}=77.4 \%, \quad$ Adjusted $R^{2}=$ $77.2 \%$

$\star$ : The significant levels for entry and staying in the stepwise procedure were controlled at the 0.05 level, respectively.

Result C3: With including Industry Dummy Variables*:

Change3 $=75.02451+6.08126$ STYIELD3 (t-statistic)

(3.79) (4.45)

+ 11.3721SLOPE - 0.1698VOLATILITY

(6.24) $\quad(-8.04)$

+ 2.94030BETA - 44.145509TYIELD3

(4.18)

$(-4.21)$

F-value* $=19.19, \quad R^{2}=3.28 \%, \quad$ Adjusted $R^{2}=$ $3.11 \%$

$\star$ : The significant levels for entry and staying in the stepwise procedure were controlled at the 0.05 level, respectively.
Finally, all explanatory variables(total eighteen IDVs) at their macro- and firm-levels (employed in the previous two methodologies of this study), were tested in a full regression, the so-called as a 'kitchen sink regression' (i.e. seven IDVS in the multiple regression model plus seven IDVs in the PCA plus four industry dummy variables) to find possible determinants of CDS spreads for the sample Korean firms utilizing stepwise procedure. Among the eighteen IDVs, four explanatory variables such as STYIELD3, SLOPE, and VOLATILITY, and BETA showed their statistically significant relationship with the DVs of CDS spreads at the 5\% level of significance. Surprisingly, the industry dummy variables did not show their consistency as significant factors to affect the DVs across the models. It was also confirmed in the full regression models that the adjusted $\mathrm{R} 2(0.93 \%)$ relating to CHANGE1 in Table 5(Result C1) was lower than that (= $77.2 \%$ ) of CHANGE2 in Result $\mathrm{C} 2$, which was in conformity with the results obtained in the multiple regression model in Table 3 .

\subsection{Interpretations}

The followings may be primary interpretations or implications on the results obtained from the procedures analyzed in the above section: The empirical test results indicate that STYIELD3, SLOPE, and VOLATILITY, and BETA showed their statistically significant relationships with the dependent variables(DVs) of the CDS spreads across the models at the $5 \%$ level of significance.

First, the IDV of STYIELD3 as a proxy for three year risk-free interest rate, showed its significant effects on each DV, as described in Table 5. The result was consistent with the finding obtained from the study of Park \& Kim[31], indicating that the risk-free interest rate was the only significant relationship with the change of the CDS spreads as a DV. However, the coefficients on the IDV showed their contradictory directions, depending on the definition of the CDS spreads such as CHANGE1 and CHAGNE3 with their positive signs and CHANGE2 with its negative one. The negative sign of the estimate of STYIELD3 relating to the CDS spreads was consistent with the results found in Abid \& Naifar[32], Avramov et al.[33] and Greatrex[34], implying that upward trend of the risk-free interest rates may be in proportion to reinvestment rates which may, in turn, result in the 
increase of a firm's value. Due to the fact that the recovery of domestic economy after the U.S. financial crisis in 2008, may be related to higher inflation and interest rates including the risk-free rate, the possibility of a firm's bankruptcy may accordingly decrease, resulting in the decrease of their CDS spreads as found in the previous research. Even if all of the estimates of STYIELD3 showed their statistically significant effects on the dependent variables(DVs) in the models, the finding with the positive estimate of STYIELD3 which was different from the results of the previous research, may arise from the base effect in the corresponding DV, as the 'change in proportion' of CDS spreads.

Second, for the IDV of SLOPE in Table 5, measuring the term structure of interest rate in this research, found the statistically significant relationships to all of the DV with all positive signs. This explanatory variable was tested in most of the previous literature as a proxy for a future business climate, in that an increasing slope may signal the recovery of domestic economic condition and vice versa, as presented in Greatrex[35]. While the expected sign of the coefficient of this particular IDV was negative in traditional finance theory as in Abid \& Naifar[36], the result of this study (with its positive sign) may result from the fact that an increasing slope may decrease the expected net present value(NPV) of (long-term based) projects or business and then eventually reduce a firm's value, as also described in Avramov et al.[37] Third, another statistically significant IDV found affecting the CDS spreads in this study, was VOLATILITY for all DVs in the tested models. This variable was also tested in the majority of the previous research such as in Ericsson et al.[38] and Kim \& Lee[39] a possible measurement of (corporate) business risk and found to have a statistically significant relationship between the volatility and the CDS spreads. In this particular study, the proxy for the VOLATILITY was calculated by the formula of (Annual equity return) $x$ (Total daily number of equity trading during a particular year) $1 / 2$ as defined in the NewKisValue. Another conventional measurement for a business risk, STD (i.e. Standard deviation of changes in EBIT during the sample period of 2009-2010), was also employed in the stepwise regression model in Table 5(Result $\mathrm{C} 2$ ) and was found to be positive and statistically significant on the CDS spreads, as expected a priori in finance.

Finally, regarding the systematic risk proxied by BETA measured in the context of the capital asset pricing model(CAPM) showed its statistically significant effect on each corresponding DV. As theorized in finance, the systematic or the market risk may not be reduced by diversification. While Abid \& Naifar.[40] found that the systematic risk of a firm could not show its influence on the CDS premium, this factor(BETA) showed its significant effect in this study, as a possible determinant of the CDS spreads. Total risk of a firm is the combination of systematic risk and unsystematic risk which can be reduced by diversification in the well-known portfolio theory. Since there seems to be an inverse relationship to affect the CDS spreads between VOLATILITY (or STD) as total risk and BETA as systematic risk, as presented in Table 5 with their opposite signs, it is plausible that lower unsystematic risk of a firm (i.e. higher of systematic risk) may result in the decrease of the level of CDS spreads as well. In order to increase systematic risk, one may consider to reorganize a firm's capital structure or financial leverage in the context of the levered beta theory, the so-called as the 'Hamada' equation in finance.

There are other implications as follows, on the IDVs found in this study, even if they showed statistically insignificant effects on the CDS spreads in the tested models or the majority of the models did not show their significance as possible determinants of the CDS spreads:

The dummy variables proxied for industry influence, were found to be significant as the possible attributes of CDS spreads in some of the models tested in this research. For example, IND1(for the automobile industry) and IND4(for the steel industry) were inversely related in the CDS spread level, while IND3(for the telecommunication industry) had a positive relationship with it, as presented in the Table 5(Result C2). According to the Myers' pecking order theory, a more profitable firm may possess its decreasing possibility of bankruptcy, due to the less burden of debt by utilizing more internally generated fund. During the sample period (from 2009 to 2010) since the U.S. financial crisis, large export-oriented Korean firms belonging to the automobile and the steel industries, also enjoyed expanding their market shares on a global basis, which resulted in higher profit or earnings. On the 
contrary, a firm belonging to a counter-cyclical industry such as the telecommunication, could not achieve increased domestic earnings, due to the recovery of domestic economy to a lesser degree. Therefore, the result obtained in this study can be interpreted that a firm belonging to the industry with higher earnings such as IND1 and IND4, may be inversely related to the CDS premia, while the reverse was true for the IND3.

Moreover, one of the IDVs, INASSETS as a proxy for size showed its negatively significant relationship with some of the DVs in the models, which was consistent with the result of Park \& Kim[41]. Even if most previous literature did not include or test the explanatory variable to find its possible influence on the CDS spreads, the followings are the implication concerning the significant result of the contemporary study: Larger firms may have higher degree of diversification through their product-mix strategies and the subsidiaries than their smaller counterparts in size, which thereby resulted in the decrease of total risk of a firm or an entity with lower CDS spreads.[42] Du and Dai[43] found that firm size may serve as an inverse proxy for unobservable credit risk implying that larger firms in size may maintain higher leverage or debt ratios due to their lower credit risk. Therefore, their finding may also provide the rationale on the result of this result, supporting the negative relationship between INASSETS and the level of CDS spreads.

[Table 6] Summary of the significant IDVs (at the 5\% level) from each regression model.

\begin{tabular}{|c|c|c|c|}
\hline MODEL & Change1 & Change2 & Change3 \\
\hline $\begin{array}{l}\text { Without } \\
\text { industry } \\
\text { Dummy }\end{array}$ & $\begin{array}{l}\text { STYIELD3,SL } \\
\text { OPE, } \\
\text { INASSET, } \\
\text { (-)VOLATILI } \\
\text { TY, }\end{array}$ & $\begin{array}{l}\text { (-)STYIELD3, } \\
\text { SLOPE, } \\
\text { (-)INASSES, } \\
\text { (-)PFT1, } \\
\text { VOLATILITY, } \\
\text { MLEVERAGE, }\end{array}$ & $\begin{array}{c}\text { STYIELD3, } \\
\text { SLOPE, } \\
\text { INASSETS, } \\
\text { (-)VOLATILI } \\
\text { TY, (-)MVBV }\end{array}$ \\
\hline $\begin{array}{l}\text { With industry } \\
\text { dummy \& the } \\
\text { stepwise } \\
\text { procedure }\end{array}$ & $\begin{array}{l}\text { STYIELD3, } \\
\text { SLOPE, } \\
(-) \text { VOLATILI } \\
\text { TY, BETA }\end{array}$ & $\begin{array}{c}\text { (-)STYIELD3, } \\
\text { SLOPE, } \\
\text { (-)INASSETS, } \\
\text { PFT1, } \\
\text { VOLATILITY, } \\
\text { MLEVERAGE, } \\
\text { (-)MVBV, } \\
\text { (-)BETA, }\end{array}$ & $\begin{array}{l}\text { STYIELD3, } \\
\text { SLOPE, } \\
\text { (-)VOLATILI } \\
\text { TY, } \\
\text { (-)TYIELD3, } \\
\text { BETA }\end{array}$ \\
\hline
\end{tabular}

\begin{tabular}{|l|c|c|}
\hline & $(-)$ PFT2, \\
GROWTH, \\
STD, MVE, \\
BLEVERAGE, \\
$(-)$ IND1, IND3, \\
$(-)$ IND4 \\
\hline
\end{tabular}

\section{Concluding Remarks}

This study examined the brief background of the recent financial crisis and the concept of one of the demanded OTC derivatives such as the credit default swap(CDS). It was performed to have potential investors acquire more knowledge on the CDS (or synthetic CDO), which may be the major financial innovative products resulting in, in large part, the unprecedented and unpleasant crises of the recent global financial markets. For example, one of the bailed-out financial intermediaries, AIG(American International Group) was stood up on the verge of bankruptcy on 2008, due to its one-side position as the seller of the CDS.[44] Moreover, this research further investigated or tested to find possible financial characteristics or attributes of the CDS spreads (or premia) for the Korean sample firms classified into the emerging capital market, utilizing more comprehensive (three) models. When selecting the time (or studied) period between the year of 2009 and 2010, consideration was given to one of the major objectives of this study to investigate the new or changing determinants in the 'post-global financial crisis', as described earlier.

Concerning the results obtained from the multiple regression models, the explanatory variables such as STYIELD3, SLOPE, INASSETS, and VOLATILITY, showed their statistically significant effects on all the tested dependent variables(DVs). Since the intercepts of the majority of the models estimating the average effects of omitted variables, showed their statistically significant at the $5 \%$ level, another procedure such as the principle component analysis(PCA), was also performed to account for additional IDVs as possible determinants of the dependent variables. Based on larger coefficients of each corresponding eigenvector, additional new IDVs such as BETA, PFT2, GROWTH, STD, and BLEVERAGE were found to be additional financial determinants. For a 
robustness test, all the IDVs (i.e. total eighteen variables) employed in the previous two methodologies, were selected to be tested in the 'full' regression model (the so-called as the 'kitchen sink' regression) with stepwise procedure. As a result, STYIELD3, SLOPE, and VOLATILITY, and BETA showed their statistically significant relationship with the CDS spreads. As the limitation of this empirical study, various results may be expected, due to employing different measures of variables and/or different time periods, as in the previous researches. To overcome this limitation to a larger degree, this particular study performed further or thorough analyses on the determinants of the CDS spreads with utilizing more comprehensive (total eighteen) explanatory variables to derive a general conclusion or results, as described earlier. Moreover, most IDVs entered into the model, were based on their commonalities in most previous literature, so that the results of this study can be used to compare their similar or different patterns between advanced capital markets and emerging capital markets. [45]

This paper sheds new light on the following issues in summary: First, as described, many investors including financial institutions and individuals, may have the opportunities to acquire their broad knowledge or information on the aspects of financial innovative products. Second, there are few systematic comparisons on the results of the financial characteristics of CDS spreads between the two markets (i.e. advanced vs. emerging capital markets), so far. In other words, even if most previous researches were performed for the firms located in the advanced capital markets, there were few studies performed for the latter markets. By taking into account the traditional proverb of "Let the past failure (e.g. the recent global financial crisis) be a good lesson.", the results obtained from this research, may be beneficial for most firms belonging to both markets, given the dynamically changing environments of rapid integration of the global financial markets. Policy makers implementing the domestic financial policies in Korea or emerging capital markets, may also consider the implication of the significant results of this study to prevent or minimize any possibilities of unanticipated financial turmoil.

\section{References}

[1] Yoon S. Park and H. Kim, "Determinants of Credit Default Swap: The Case of Korean Firms," The Korea Academia-Industrial Cooperation Society, Vol.12, No.10, pp. 4359-4368, 2011.

[2] H. Kim, "The Financial and Legal Characteristics of "Credit Default Swap(CDS)," Advanced Commercial Law Review, Vol.54, pp.83-113, 2011.

[3] Yoon S. Park, (2009). "The Role of Financial Innovations in the Current Global Financial Crisis." Seoul Journal of Economics, Vol.122, pp. 123-144, 2009.

[4] Yoon S. Park and H. Kim, "Determinants of Credit Default Swap: The Case of Korean Firms," The Korea Academia-Industrial Cooperation Society, Vol.12, No.10, pp. 4359-4368, 2011.

[5] Yoon S. Park, (2009). "The Role of Financial Innovations in the Current Global Financial Crisis." Seoul Journal of Economics, Vol.122, pp. 123-144, 2009.

[6] H. Kim, "The Financial and Legal Characteristics of "Credit Default Swap(CDS)," Advanced Commercial Law Review, Vol.54, pp.83-113, 2011.

[7] Global CDO Issuance,2000-2010<http://www.sifma.org>

[8] R. Blanco, et al., "An Empirical Analysis of the Dynamic Relation Between Investment-grade Bonds and Credit Default Swaps," Journal of Finance, Vol. 60,.pp. 2255-2281, 2006.

[9] F. Abid, and N. Naifar, "The Determinants of Credit Default Swap Rates: An Explanatory Study," International Journal of Theoretical and Applied Finance, Vol. 9, pp. 23-42, 2006.

[10] D. Avramov et al., "Understanding Changes in Corporate Credit Spreads," Financial Analyst Journal, Vol. 64, pp. 90-105, 2007.

[11] J. Ericsson et. al., "The Determinants of Credit Default Swap Premia," Journal of Financial and Quantitative Analysis, Vol.44, pp. 109-132, 2009.

[12] C. A. Greatrex, "Credit Default Swap Market Determinants," Journal of Fixed Income, pp. 18-32, Winter, 2009.

[13] M. Kim and J. Lee, "A Study of Determining the Spreads of Won-denominated Credit Default Swap," The Korean Journal of Finance, Vol. 20, pp. 1-32, 2007.

[14] Yoon S. Park and H. Kim, "Determinants of Credit Default Swap: The Case of Korean Firms," The Korea Academia-Industrial Cooperation Society, Vol.12, 
No.10, pp. 4359-4368, 2011.

[15] D. Avramov et. al., "Understanding Changes in Corporate Credit Spreads," Financial Analyst Journal, Vol. 64, pp. 90-105, 2007.

[16] C. A. Greatrex, "Credit Default Swap Market Determinants," Journal of Fixed Income, pp. 18-32, Winter, 2009.

[17] D. Avramov et. al., "Understanding Changes in Corporate Credit Spreads," Financial Analyst Journal, Vol. 64, pp. 90-105, 2007.

[18] C. A. Greatrex, "Credit Default Swap Market Determinants," Journal of Fixed Income, pp. 18-32, Winter, 2009.

[19] J. Ericsson et. al., "The Determinants of Credit Default Swap Premia," Journal of Financial and Quantitative Analysis, Vol.44, pp. 109-132, 2009.

[20] C. A. Greatrex, "Credit Default Swap Market Determinants," Journal of Fixed Income, pp. 18-32, Winter, 2009.

[21] H. Kim and Paul. D. Berger, "A Comparison of Capital Structure Determinants: the United States and the Republic of Korea," Multinational Business Review, Vol. 16, pp. 79-100, 2008.

[22] H. Kim, "Inter-and Intra-leverage Analyses for Large Firms in the United States and Korea," Journal of Asia-Pacific Business, Vol.10, pp. 34 - 64, 2009.

[23] D. Avramov et. al., "Understanding Changes in Corporate Credit Spreads," Financial Analyst Journal, Vol. 64, pp. 90-105, 2007.

[24] J. Ericsson et. al., "The Determinants of Credit Default Swap Premia," Journal of Financial and Quantitative Analysis, Vol.44, pp. 109-132, 2009.

[25] A. Afifi and V. Clark, Computer-aided Multivariate Analysis (2nd ed.), Chapman \& Hall, New York, 1990.

[26] H. Kim and Paul D. Berger, "The Management Characteristics of Korean Chaebols vs. non-Chaebols: Differences in Leverage and Its Ramifications: Myth or Reality?" Advanced In Management, Vol. 2, No. 11, pp. 26-35. 2009.

[27] V. A. Palenzuela and A. M. Bobillo, "Financial Structures of Spanish Firms: Multinational vs. Domestic," Multinational Business Review, pp. 64-79, Fall, 1994.

[28] J. Ericsson et. al., "The Determinants of Credit Default Swap Premia," Journal of Financial and Quantitative Analysis, Vol.44, pp. 109-132, 2009.

[29] Yoon S. Park and H. Kim, "Determinants of Credit Default Swap: The Case of Korean Firms," The Korea
Academia-Industrial Cooperation Society, Vol.12, No.10, pp. 4359-4368, 2011.

[30] A. Afifi and V. Clark, Computer-aided Multivariate Analysis (2nd ed.), Chapman \& Hall, New York, 1990.

[31] Yoon S. Park and H. Kim, "Determinants of Credit Default Swap: The Case of Korean Firms," The Korea Academia-Industrial Cooperation Society, Vol.12, No.10, pp. 4359-4368, 2011.

[32] F. Abid, and N. Naifar, "The Determinants of Credit Default Swap Rates: An Explanatory Study," International Journal of Theoretical and Applied Finance, Vol. 9, pp. 23-42, 2006.

[33] D. Avramov et. al., "Understanding Changes in Corporate Credit Spreads," Financial Analyst Journal, Vol. 64, pp. 90-105, 2007.

[34] C. A. Greatrex, "Credit Default Swap Market Determinants," Journal of Fixed Income, pp. 18-32, Winter, 2009.

[35] C. A. Greatrex, "Credit Default Swap Market Determinants," Journal of Fixed Income, pp. 18-32, Winter, 2009.

[36] F. Abid, and N. Naifar, "The Determinants of Credit Default Swap Rates: An Explanatory Study," International Journal of Theoretical and Applied Finance, Vol. 9, pp. 23-42, 2006.

[37] D. Avramov et. al., "Understanding Changes in Corporate Credit Spreads," Financial Analyst Journal, Vol. 64, pp. 90-105, 2007.

[38] J. Ericsson et. al., "The Determinants of Credit Default Swap Premia," Journal of Financial and Quantitative Analysis, Vol.44, pp. 109-132, 2009.

[39] M. Kim and J. Lee, "A Study of Determining the Spreads of Won-denominated Credit Default Swap," The Korean Journal of Finance, Vol. 20, pp. 1-32, 2007.

[40] F. Abid, and N. Naifar, "The Determinants of Credit Default Swap Rates: An Explanatory Study," International Journal of Theoretical and Applied Finance, Vol. 9, pp. 23-42, 2006.

[41] Yoon S. Park and H. Kim, "Determinants of Credit Default Swap: The Case of Korean Firms," The Korea Academia-Industrial Cooperation Society, Vol.12, No.10, pp. 4359-4368, 2011.

[42] H. Kim and Paul. D. Berger, "A Comparison of Capital Structure Determinants: the United States and the Republic of Korea," Multinational Business Review, Vol. 16, pp. 79-100, 2008.

[43] J. Du and Y. Dai, "Ultimate Corporate Ownership Structures and Capital Structures: Evidence from East 
Asian Economies," Corporate Governance: An

International Review, Vol. 13, No. 1, pp. 60-71, 2005.

[44] H. Kim, "The Financial and Legal Characteristics of "Credit Default Swap(CDS)," Advanced Commercial Law Review, Vol.54, pp.83-113, 2011.

[45] The data employed in this study are available upon request from the author.

\section{Hanjoon Kim}

[regular member]

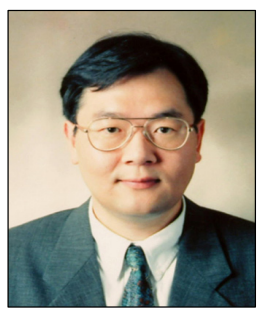

- Sep. 1987 : The George Washington Univ., MBA

- Jan. 1999 : Boston University DBA (Major: Finance)

- Mar. $2010 \sim$ current : Hoseo Univ. Dept. of Business Administration, Assistant Professor

$<$ Research Interests $>$

Corporate Finance, International Finance, Mergers \& Acquisitions, Valuation 